\title{
Engagement Policy Towards Repatriated Indonesian Women from Overseas Jihad Battlefronts
}

\author{
N W Veronika ${ }^{1}$, D A P E Wishanti ${ }^{2}$ \\ ${ }^{1}$ Coordinating Ministry of Political, Legal, and Security Affairs; Republic of Indonesia \\ ${ }^{2}$ International Relations Program, Universitas Brawijaya, Malang, Indonesia \\ 1uri.widiastuti@polkam.go.id, ${ }^{2}$ e.wishanti@ub.ac.id
}

\begin{abstract}
Transnational violent attacks and extremism often considered as a men's landscape. Violent ideology and guns are also distributed globally by groups of men. However, this phenomenon started to shift along with the rise of ISIS. Women emerged as a vital group to propaganda and executive role of terrorist attacks across the globe, given their innocent and passive stereotypes. Following ISIS' downfall, their followers including male and female, excombatants, women and children followers hope to better their conditions by returning to their home countries. Government of Indonesia faces several dilemmas on this, whether to repatriate or not. In addition to that, Indonesian agencies have not fully aware that women could serve both as messenger of extreme ideology propaganda and as the important witnesses to blow up ISIS' wrongdoings. Current policies are not produced with adequate gendered perspectives and aims. This paper would fill the existing gap of gendered paradigm by inserting the framework of inclusion of gender role in preventing and countering violent extremism policymaking process., especially in preparing for the repatriation of Indonesian women from ex ISIS camps. This paper also identifies the broader role the women plays during their jihad experience overseas and what kinds of threats they can possess while returning home. To conclude, women experts and officers should not be marginalized further in counter extremism efforts at home, as they can tear down psychological and cultural barrier in policymaking inputs.
\end{abstract}

Keywords: Women Returnees, Violent Extremism, Gendered Policymaking Process, Jihad, ISIS

\section{INTRODUCTION}

Women has been excluded from the conversation of international security issues for ages. However, the important position of women in security issues can not be seen as minimal over time. Despite the important role of women in spreading the values in the family, technological developments seemed to expose women to propaganda of violent extremism. Data from the Association of Internet Providers of Indonesia (APJII), noted that in 2017, the internet-users in Indonesia have reached 143.26 million, the equal of 54.68 per cent of its 262 million population[1]. Dian, Dita, Siska, Puji Kuswati (Surabaya Suicide Bomber), and Solimah (Sibolga female bomber) were all exposed to ISIS materials on the internet and communicate with their ISIS-links through several applications as Whatssapp, Facebook and Telegram. Therefore, the massive information and communication technology (ICT) 
development in Indonesia without the balanced literacy on terrorism and violent extremism propaganda have led more and more women to fall into justifying brutal acts of terrorism and sacrificing their own families and children for what they believe to be the greater cause.

On a broader scope, between 1985 to 2010, 257 suicide bombs were blown by female "insurgents" including the newly Muslim-converted ones and the jihadists. This is a multidimensional pattern of occurences and should not be disengaged from government policymaking process, as the approach used for the process might be less accurate in determining the cause of the problem. Women are considered as passive terrorist actors and therefore pose less threats than their men counterparts. As a result, women often found themselves easier to pass security forces on state borders and other public areas. Moreover, a child company or a state of pregnancy would stand as a inquestionable cover for their premeditated actions.

However, after the downfall of Islamic State in Iraq and Syria (ISIS) "caliphate" in 2017, many Indonesia-originated women and children were displaced in ISIS camps. They were exposed to instant threats of militias, hunger, and most notably the risk of further radicalization. Rough estimation of 120 women in exile are detected to have the possibility to become a returnee (July 2019), reaching 160 (October 2019), returned 2 women (self repatriation) in 2019. Updated data on Foreign Terrorist Fighters (FTF) from National Agency of Terrorism Eradication (BNPT) shows the number is a lot bigger than the prediction. Controversies arise in domestic public opinion upon how to exercise policy on women returnees as they were proven to possess similar threats to men jihadists.

The assumptions above will be further investigated whether the phenomenon of women extremists is a result of policymaking failure of the state in combating violent extremism. To date, Indonesia had completed the Revision of the Anti-Terrorism Law in 2018 (Act Number 5 Year 2018 about the Amendment of Law Number 15 Year 2003 About the Legalization of Government Regulation In Lieu Of The Law Number 1 Year 2002 on Eradication of Terrorism Acts). The law seems to provide minimal context to address women in counterterrorism and counter-radicalism narratives emphasizing on soft approach i.e. deradicalization efforts. There is no specific article in the Indonesia terrorism law that refers to women's involvement and mitigation and prevention mechanisms that can be carried out to anticipate the increasing role of women in acts of terrorism and violent extremism.

Although it is impossible to simplify myriad of motivations to a single factor, the selfidentity factor is hypothetically the strongest motivation for the involvement of women in terror networks. From the various examples of women's involvement in terrorism, women who were lured to follow the extremist path are not helpless ones. They have access to resources, for example finance and education. Becoming part of terrorist activism, a radicalized woman can easily identify herself as "more established" in terms of religious perfection.

Modern day life has led to increasingly complex human life, with a stronger culture of consumerism, egocentrism, corruption, injustice and loss of religious values held by society so far. This can cause a devout and faithful person to question of the righteousness of the world they dwell in. Further reflections of their mindset toward their basic existence is radicalized, moreover, sense of belonging to their home countries is sharply declined. Crisis of identity and questions like this continue to interfere someone's mind who has been exposed to radical ideology to find an existence that is worthy of their beliefs[2].

However, there are other factors which have specifically driven women to join terrorist groups and finally decided to do hijrah to ISIS territory. Social media has provided opportunities for women to become exposed to extreme ideologies and link to other 
sympathizers and recruiters. They are led to believe that they have been given a sense of empowerment of having more important roles in terrorist acts. This allows women to gain greater freedom to engage in a wider array of activities such as recruiting potential converts, distributing propaganda and mobilizing sympathizers as well as perpetrating actual terrorist acts[3].

In regards to women returnees issue, the Indonesian government is in a tight bind to deal with this. Despite resisstane to repatriation of those ISIS followers back home, Preamble of the Indonesian 1945 Constitution highlights that Indonesian should protect the entire Indonesian nation and the whole of Indonesia's bloodshed, including women now detained at Al howl, Al Roj and Ain Issa camps.

This manuscript would emphasize on state response towards women returnees as a group of people with certain identity. Studies on this part have been developed fairly in the academia. On the other side, government policymaking process and involvements are often considered to utilize less terror-preventive measures and frequently employs punitive justice approaches.

Previous studies have indicated that overseas Indonesian foreign fighters flow is not a novel phenomenon. Many of the fighters had fled the country to become Afghan Mujahidin during the 1980s and early 1990s. Two prominent clerics resided in Indonesia, namely Abu Bakar Ba'asyir and Abdullah Sungkar promoted the migration to Afghan military camps to fight the Soviets. However, local crackdown in Tanjung Priok during Indonesia New Order Era motivated the fighter to return home, then to topple down the incumbent government at that time. Nevertheless, the role of the women is not clearly mentioned in this study. However, the study mentioned that in contrast to the Cold war era, women returnees post-ISIS downfall tended to change their stories frequently to NGO or research interviewers, thus making it difficult to validate their answers of their motives and reasons.

On the other side, "returnees" as a term, have a vague definition and categorization. The difficulties to classify those who returns have been found by Institute for Policy Analysis of Conflicts (IPAC). Those who had involved or seen a combat overseas are included as "returnees", however, those who were once a humanitarian aid "jihadists" could also be contained within "returnees" group[4]. Other subversive women may not be included as returnees as they are not expose immediate danger toward national security. This calls for a complex handling by the governments as there is no single solution to fit all returnees' categories, particularly on women.[5]

\section{RESEARCH METHOD}

The authors employed in-depth interviews and literary studies to gather data and information. Women returnees are classified as those who returned from jihad battlefront outside Indonesia by their own conscious reasons, strictly limited to those who felt that they had been deceived by the jihadist promotors. Government officials from related agencies are also involved as resource persons as a form of verification of interview results. The information is then coded and reduced into a structurized and patterned answers. Interpretation on this raw data is based on the conceptual framework below.

This manuscript is framed with gender equality as a tool of countering violent extremism; therefore inclusion of gender approaches should be implemented in national policymaking process. Gender approach has a strategic necessity in development of peace, where empowered groups of women would result in a vastly more secured nation. In addition, 
women are portrayed to be non-violent, innately maternal, and other softer attributes. However, with such traits, women are prone to be manipulated and patronized[6].

Role of inclusive gendered approach in government sphere are as follows. First, to support security actors with vital information. Second, to count women returnees' experiences to prevent future counterproductive measures. Third, involvement of women in security agencies and law enforcement bodies to further penetrate gender barriers and cultural expectations. Lastly, women can assume a position as a political leader to ensure the effectivity of policy implementation[7].

\section{RESULTS AND DISCUSSION}

The wave of migration (hijrah) of Indonesian women to ISIS territory since 2014 until its downfall in late 2017 has been problematic for the Indonesian government. In the period 2015-2017, 430 Indonesians were deported from Turkey and most of them were women and children. In 2018, Indonesian government repatriated 18 people (mostly women and children) and in 2019 there were 2 women successfully self-repatriated back from the war zone. From 2018 to mid-2019, more than 300 Indonesian women are now living in refugee camps in Iraq and Syria, waiting for government decision of their repatriation[8]. Domestically, this issue raises pros and cons as they are seen to pose potential security threats to national security.

FIGURE 1. Number of FTF in Syria and Iraq (28 October 2019)

\begin{tabular}{|l|l|l|l|}
\hline Category & Male & Female & Total \\
\hline Adult & 235 & 343 & 578 \\
\hline Children & 309 & 392 & 701 \\
\hline Unidentified & 133 & 1 & 134 \\
\hline & & & \\
\hline
\end{tabular}

\section{Source : BNPT (2019)}

These women have varied characteristics. First, an increasing number of ISIS-related women had borne children during jihad. Second, many women are still affiliated with ISIS fighters in various conditions and hopes for their future. They might want to stay as well as to return home. Third, as the male jihadists death number rises in battle, the proportions of women and minors are growing significantly. Therefore, they should be treated as a significant community to be addressed in combating extremism.

When incorporated in a violent or terrorist organization, women play broad roles such as facilitators, recruiters, financial aid brokers, networkers, messengers, suicide bombers, and frontline fighters. With such adept structural roles, women should not be depicted as a frail group while they actively contribute in violent extremism within their own ranks. Therefore, government strategies and policies should be formed with gendered approaches in their decision-making process.

On the other side, intrastate coordination to address these women returnees is often challenged by bureaucratic fragmentation. Perspectives among them are often clashed on the discourse of repatriation, rehabilitation, and reintegration. Current government responses and policies by each agency are explained as follows. 
In addition to that, the Indonesian key agencies are struggling to hold onto the same narrative, as each has its own ways of perceiving ISIS women followers. One said they are victims, another mentioned they are perpetrators. As ISIS may have predicted its downfall, it urged its women sympathizers to have more active roles as recruiters, financial and logistics providers and fighters. ISIS seemed to have provide a sense of empowerment for women, when actually ISIS had only twisted the words of Gods to take advantages of women to support its falling cause.

ISIS mobilized women to recruit, reward and retain male foreign fighters. This shows that ISIS women followers, disregarding whatever roles they partake in, are always the victims of ISIS propaganda and manipulation[9]. IPAC Report released in August 2019 also stated that the longer the women stayed inside the camps, the more they are exposed to violence, threats and deeper radicalism. Thus, determining the same perspective on Indonesian women returnees will be really helpful in speeding up the political decision whether to bring them home or not.

FIGURE 2. The Role of Indonesian Government Agencies to Counter Violent Extremism

\begin{tabular}{|c|c|c|}
\hline No & Key Agency & Central Role \\
\hline 1 & $\begin{array}{l}\text { Coordinating } \\
\text { Ministry For } \\
\text { Political, Legal } \\
\text { And Security } \\
\text { Affairs }\end{array}$ & 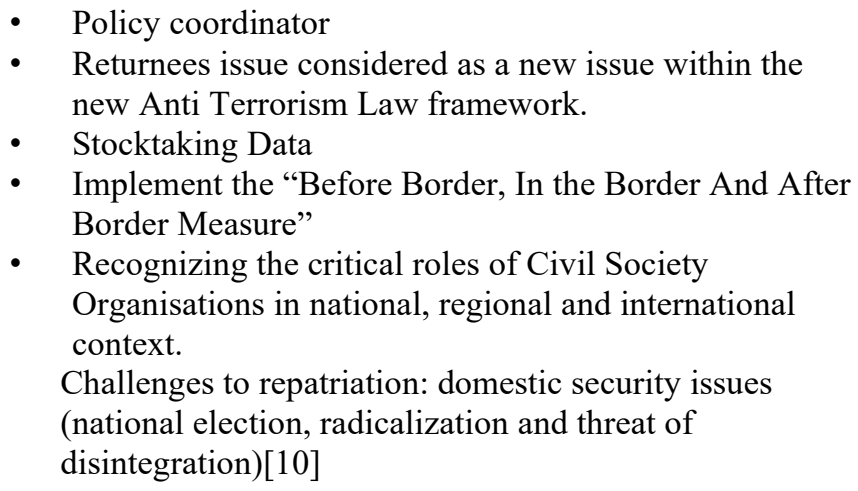 \\
\hline 2 & $\begin{array}{l}\text { National Agency } \\
\text { for Combating } \\
\text { Terrorism } \\
\text { (BNPT) }\end{array}$ & $\begin{array}{l}\text { FTF Task force (Intelligence sub-directorate in BNPT) } \\
\text { focus on data management and CT-related intelligence } \\
\text { operations. } \\
\text { Field team from various agencies (National Police and } \\
\text { Armed Forces) for initial preparation. } \\
\text { - Coordination meetings and focus group discussion } \\
\text { Regular report to Coordinating Ministry for Political, } \\
\text { Legal and Security Affairs. } \\
\text { Plus: experience from former repatriation in } 2017 \text { (18 } \\
\text { returnees) }\end{array}$ \\
\hline
\end{tabular}




\begin{tabular}{|c|c|c|}
\hline 3 & $\begin{array}{l}\text { Ministry of } \\
\text { Foreign Affairs }\end{array}$ & $\begin{array}{l}\text { Identification of Indonesian returnees with the help of } \\
\text { third party (ICRC) and maintaining communication } \\
\text { with surrounding countries Syria, Iraq, Turkey. } \\
\text { Repatriation based on request. } \\
\text { Experienced with repatriation of Indonesian citizens } \\
\text { (migrant workers) from Syria } 2012-2014 \text {, repatriation } \\
\text { of returnees in } 2017 \text { (18 people), sharing of practices } \\
\text { and information with other countries (US, France, } \\
\text { Russia, Marocco, Norway, Uzbekistan, Kazakhkistan, } \\
\text { Sudan, Belgia and Kosovo). }\end{array}$ \\
\hline 4 & $\begin{array}{l}\text { Ministry for } \\
\text { Women } \\
\text { Empowerment } \\
\text { And Children } \\
\text { Protection }\end{array}$ & $\begin{array}{l}\text { - National Action Plan for the Protection and } \\
\text { Empowerment of Women and Children in Social } \\
\text { Conflict } 2019-2024 \\
\text { - Women and security issue in relation to terrorism } \\
\text { should be included in the government regulations of the } \\
\text { Law no } 52018 \text { about Counter Terrorism. } \\
\text { Emphasis on women returnees as victims (needs } \\
\text { specific measures). } \\
\text { - } \quad \text { Collaborating with CSOs } \\
\text { - } \text { recific legal procedure for returnees to protect their } \\
\text { Distinctive data based on age, gender, and } \\
\text { vulnerabilities (measures to handle women and children } \\
\text { returnees should be different and specific). } \\
\text { - Collaboration with other related agencies. } \\
\text { Pressure to local government for reintegration of } \\
\text { returnees as victims of social conflict (related to } \\
\text { ideology) }\end{array}$ \\
\hline 5 & $\begin{array}{l}\text { Ministry for } \\
\text { Social Affairs }\end{array}$ & $\begin{array}{l}\text { Preparing for facilities to handle social rehabilitation for } \\
\text { returnees in Jakarta, Aceh, Riau, Jambi, Magelang, } \\
\text { Mataram, Kupang dan Makasar } \\
\text { Close coordination with Densus } 88 \text { National Police and } \\
\text { National Inteligence Body } \\
\text { SOP for returnees has been prepared with the help of C- } \\
\text { SAVE (CSO)[8]. }\end{array}$ \\
\hline 6 & $\begin{array}{l}\text { Ministry of Law } \\
\text { And Human } \\
\text { Rights }\end{array}$ & $\begin{array}{l}\text { Detention centres or women returnees : Detention } \\
\text { facility in Polda Metro Jaya Jakarta, correctional } \\
\text { institution in Tangerang, Bandung and Malang.[11] } \\
\text { Deradicalization programs inside detention facilities } \\
\text { require assistance from BNPT }\end{array}$ \\
\hline
\end{tabular}




\begin{tabular}{|l|l|l|}
\hline 7 & $\begin{array}{l}\text { National Police } \\
\text { (Special } \\
\text { Detachment } \\
\text { 88/DENSUS 88) }\end{array}$ & $\begin{array}{l}\text { Employing soft approach and humanistic strategy to } \\
\text { win the heart and instill trust of the returnees. } \\
\text { Women returnees are loyal followers and coming back } \\
\text { to Indonesia is the last resort, since the Caliphate is not } \\
\text { what they really hoped for. } \\
\text { Limited experienced women officers to handle and } \\
\text { address women returnees' specific needs (2 Densus } \\
\text { women officers for all returnees). } \\
\text { Returnees as the agent of peace, to prevent more people } \\
\text { join extremist group (such as Dhania, a returnee from } \\
\text { Syria in 2017). } \\
\text { Densus has no official instrument to assess the returnees } \\
\text { in situ, but implementing an "emotional/personal } \\
\text { approach"'[12]. } \\
\text { Open to collaboration with agencies concern with } \\
\text { women returnees (ministries, CSOs, and academia) }\end{array}$ \\
\hline
\end{tabular}

Source : compiled by authors

Based on the policies implemented by Indonesian key agencies, it is critical to insert a gender-based policy for women returnees, to cater for specific gender needs in dealing with this issue. BNPT, as the leading role of countering violent extremism program, should provide deradicalization facilities and activities specifically designed for women returnees before repatriation is decided. Ministry for Women Empowerment and Children Protection should keep on advocating the returnees' issue to be inserted in the new National Action Plan for the Protection and Empowerment of Women and Children in Social Conflict 2019-2024. In addition, women, peace and security issue related to countering violent extremism and counter terrorism should be included in the government regulations of the Act no 52018 about Counter Terrorism.

Policymakers in developing countries have strong tendencies to view transnational crimes and violent extremism using obsolete gender stereotypes, thus making the policy formulation often missed the problem. Preventing and countering terrorism programs are also often targeted and designed for men combatants, who are portrayed to be leaders of faith in household up to government leadership. This pattern of thinking of a maledominated violent organization structures may vary over time, as terrorist and violent attacks modus are also evolved over time[13].

Therefore, women and girls' perspective could not be marginalized any further. Tables above shows that state apparatus are playing the administrative role to a legal extent, and often limited by their own product of law. Limited by human rights principles and covenants, the government of Indonesia often find it challenging to conduct extreme measures to dig in information, while other countries are starting again to use ferocious methods of intelligence gathering such as waterboarding and thrilling confinement.

Women returnees, on the other side, perform as intergenerational hub where generations of violent extremists may be proliferated and stopped as well. It has been proven that women could also reinforce gender perception, even in many cases, women encourage men to join jihadist insurgency as well as shaming other men who did not join the cause[14]. Other manuscript also mentioned that one of ISIS tactics in propaganda 
was to instruct women and children as a envoy of shame and emasculation[15]. This potential should also be considered in policymaking and lawmaking process.

\section{CONCLUSIONS}

Careful preparation for the repatriation process is the key to reduce and eliminate national security threat posed by women returnees. More research on this issue is imperative in assisting policy formulation process, law enforcement procedure rehabilitation and reintegration phase of the returnees.

\section{ACKNOWLEDGEMENT}

Both authors are doctoral scholarship awardees from Indonesia Endowment Fund for Education Agency (LPDP), Ministry of Finance, Republic of Indonesia. This research is also fully supported by Coordinating Ministry of Political, Legal, and Security Affairs Republic of Indonesia.

\section{REFERENCES}

[1] S. Yuniarni, "Indonesia Had 143m Internet Users in 2017: APJII | Jakarta Globe," JakartaGlobe. 2018.

[2] "Noorhaidi Hasan Laskar Jihad: Islam, Militancy, and the Quest for Identity in PostNew Order Indonesia Ithaca, New York: Cornell Southeast Asia Program Publications. 2006, 266p.," Southeast Asia Hist. Cult., 2008.

[3] L. Huey and E. Witmer, "\#IS_Fangirl: Exploring a New Role for Women in Terrorism," J. Terror. Res., 2016.

[4] E. Karagiannis et al., "Foreign Fighters: How Are They Being Recruited? Two Imperfect Recruitment Models," Stud. Confl. Terror., 2014.

[5] IPAC, "The Re-Emergence of Jemaah Islamiyah," 2017.

[6] S. Patel and J. Westermann, "Women and Islamic-State Terrorism : An Assessment of How Gender Perspectives Are Integrated in Countering Violent Extremism Policy and Practices," Secur. Challenges, 2018.

[7] I. Idris, "Preventing / countering violent extremism programming on men, women , boys and girls," 2019.

[8] "Countering violent extremism in Indonesia: priorities, practice and the role of civil society," J. Deradicalization, 2017.

[9] M. Bloom, "Bombshells: Women and terror," Gender Issues, 2011.

[10] L. Suryadinata, "Singapore | 25 July 2018 Islamism and the New Anti-Terrorism Law in Indonesia," no. 39, pp. 1-7, 2018.

[11] D. M. Mengko, "Pelibatan TNI dalam Kontra Terorisme Di Indonesia," J. Penelit. Polit., 2017.

[12] A. Damayanti, "Is Counter Terrorism in Indonesia a Triumph ?," vol. 2, no. November 2011, pp. 27-42, 2012.

[13] S. J. Jacobsen, "Terrorism Research Initiative Calling on Women Female-Specific Motivation Narratives in Danish Online Jihad," Source Perspect. Terror., vol. 13, no. 4, pp. 14-26, 2019.

[14] S. V. Raghavan and V. Balasubramaniyan, "Evolving role of women in terror groups: Progression or regression?,” J. Int. Womens. Stud., 2014. 
[15] A. Beutel et al., "Guiding Principles for Countering and Displacing Extremist Narratives," J. Terror. Res., 2016. 